\title{
Cadillac care for the poor... addressing local health emergency around STDs and HIV in an urban community-based medical home
}

\author{
Larisa Kudryashova-Hernandez \\ From 17th International Symposium on HIV and Emerging Infectious Diseases (ISHEID) \\ Marseille, France. 23-25 May 2012
}

\section{Background}

NHSC, an urban community-based health center in Plainfield, Union County, NJ, USA, provides services to 25,000 uninsured/minority/impoverished patients. Plainfield consistently ranks first and second among the 29 Union County municipalities for Syphilis, Gonorrhea and Chlamydia. Plainfield ranks second for the numbers of HIV/AIDS. There is, therefore, a dire need to address the existing health emergency around STDs and its correlation with HIV.

\section{Methods}

NHSC incorporates a coordinated, proactive, patientcentered approach to integrating STD screening/prevention with primary care in a medical home environment. Risk assessments/screenings are done by clinicians. Those identified suspicious for STD or with STD symptoms/diagnosis receive on-the-spot HIV counseling and Rapid testing. Patients receive immediate treatment intervention for suspected STDs. There are on-going prevention efforts including development of Risk Reduction Plans agreed upon/signed by patients.

\section{Results}

Resulting from the integrated STD/HIV prevention approach: $100 \%$ of patients presenting with symptoms/ suspicion for STDs received HIV counseling/Rapid testing; $100 \%$ received prevention education and free condoms; 100\% had Risk Reduction Plans developed and agreed upon; 19 persons were identified STD and HIV positive and were immediately linked to care.
Correspondence: Lara0822@yahoo.com

Ancillary HIV Services at Neighborhood Health Services Corporation, Plainfield, USA

\section{Conclusions}

Integration of STD/HIV prevention with outpatient care under the umbrella of Early Intervention Services allowed to: identify extend of STD/HIV correlation; allow for a seamless one-stop shop prevention-treatment service delivery model; improve patient awareness of onsite prevention/treatment resources.

Published: 25 May 2012

doi:10.1186/1742-4690-9-S1-P74

Cite this article as: Kudryashova-Hernandez: Cadillac care for the poor... addressing local health emergency around STDs and HIV in an urban community-based medical home. Retrovirology 2012 9(Suppl 1):P74.
Submit your next manuscript to BioMed Central and take full advantage of:

- Convenient online submission

- Thorough peer review

- No space constraints or color figure charges

- Immediate publication on acceptance

- Inclusion in PubMed, CAS, Scopus and Google Scholar

- Research which is freely available for redistribution

Submit your manuscript at www.biomedcentral.com/submit
() Biomed Central

\section{Ciomed Central}

